University of Rhode Island

DigitalCommons@URI

The Rhode Island Current Conditions Index

Economics

$1-2007$

\title{
Rhode Island Current Conditions Index - January 2007
}

Leonard Lardaro

University of Rhode Island, lardaro@uri.edu

Follow this and additional works at: https://digitalcommons.uri.edu/ricci

Part of the Econometrics Commons

Terms of Use

All rights reserved under copyright.

\section{Recommended Citation}

Lardaro, Leonard, "Rhode Island Current Conditions Index - January 2007" (2007). The Rhode Island Current Conditions Index. Paper 70.

https://digitalcommons.uri.edu/ricci/70

This Article is brought to you for free and open access by the Economics at DigitalCommons@URI. It has been accepted for inclusion in The Rhode Island Current Conditions Index by an authorized administrator of DigitalCommons@URI.For more information, please contact digitalcommons-group@uri.edu. 


\section{CURRENT EONDITIONS Index

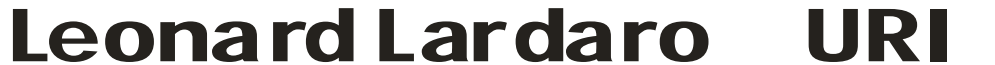

The recently revised labor market data paint a somewhat different picture of the way our economy actually performed last year. The acceleration in Rhode Island's economic momentum didn't actually occur until year's end. The time period for sluggish activity, from April through August of last year, remained with the newly revised data. Fortunately, the fourth-quarter momentum has carried into the new year. The Current Conditions Index for January was 58, as seven of the twelve indicators improved. Three of the improving indicators turned in strong performances, while weakness in housing, which has carried over into Retail Sales, continued.

The strongest performances in January were for Employment Service Jobs, Private Servicing-Producing Jobs, and the Unemployment Rate. Importantly, the first of these is a leading indicator, pointing to some potential strength as we move further into 2007.

Employment Service Jobs, which includes temporary employees, rose by 15.0 percent, its fourth consecutive double-digit increase. Data on this indicator was revised higher for much of last year as well. Private Service Producing Employment growth was very healthy, at 2.3 percent in January. This has sustained an above one percent growth rate since September of last year. And, our Unemployment Rate

\begin{tabular}{lc}
\multicolumn{2}{c}{ CCI Indicators - \% Change } \\
Government Employment & -0.9 \\
US Consumer Sentiment & 6.0 Y \\
Single-Unit Permits & -8.3 \\
Retail Sales & -5.4 \\
Employment Services J obs & 15.0 Y \\
Priv. Serv-Prod Employment & $2.3 \mathrm{Y}$ \\
Total Manufacturing Hours & -1.3 \\
Manufacturing Wage & $1.2 \mathrm{Y}$ \\
Labor Force & $1.1 \mathrm{Y}$ \\
Benefit Exhaustions & $-4.8 \mathrm{Y}$ \\
New Claims & 1.2 \\
Unemployment Rate & $-9.6 \mathrm{Y}$ \\
\multicolumn{1}{c}{ Y = I mproved Value } &
\end{tabular}

fell sharply, from 5.2 percent last January to 4.7 percent this January. More importantly, the very high jobless rates from the data originally released for last year were largely revised down. The highest Unemployment Rate last year was 5.2 percent, not the 5.6 percent rate that was originally reported.

Single-Unit Permits, which reflects new home construction, continued its roller coaster ride, falling by 8.3 percent in
January. And, when housing falters, Retail Sales often follows. Retail Sales fell by 5.4 percent in January. It should be noted, however, that the declines in both of these indicators followed atypically strong increases ("comps") last January. And, US Consumer Sentiment grew by 6.0 percent in January, its fifth consecutive monthly increase.

In January, Rhode Island's manufacturing sector turned a mixed performance. The Manufacturing Wage rose by 1.2 percent, continuing the slowdown in its rate of growth that began last November, while Total Manufacturing Hours fell by (only) 1.3 percent, sustaining its trend of smaller declines of late. The slowing rate of decline in Total Manufacturing Hours this month was caused by an increase in the length of the manufacturing workweek which offset the fall in the number of manufacturing employees. The length of the manufacturing workweek has gained momentum of late.

Government Employment fell again, by 0.9 percent, its sharpest decline in over a year. Labor Force growth moved back above one percent for the first time since last November. And, a critical labor market "pair" failed to improve for the third consecutive month. New Claims for Unemployment Insurance, which measures layoffs, rose by 1.2 percent in January, continuing its recent upward trend, while at the other end of the layoff spectrum, Benefit Exhaustions, which reflects long-term unemployment, fell by 4.8 percent.

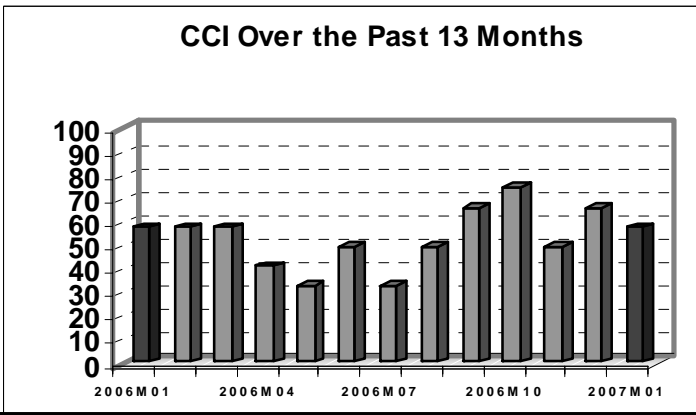

THE BOTTOM LINE

The recent rebenchmarking of Rhode Island's labor market data didn't bring about major changes to the overall levels of the Current Conditions Index last year, but it did shift the point at which our momentum picked from the first to the fourth quarter. As is so often the case, when the national economy slows, Rhode Island's economy seems to gain momentum.

\begin{tabular}{|c|c|c|c|c|c|c|c|c|c|c|c|c|c|}
\hline & \multicolumn{1}{c}{ Jan } & Feb & Mar Apr & May Jun Jul Aug Sep Oct Nov Dec \\
2006 & 58 & 58 & 58 & 42 & 33 & 50 & 33 & 50 & 67 & 75 & 50 & 67 \\
2007 & 58 & & & & & & & & & & & \\
\hline
\end{tabular}

